\title{
Feministic Analysis of Arundhati Roy's the God of Small Things in the Light of Post Colonialism
}

\author{
Shiva Zaheri Birgani ${ }^{1}$, Sayyed Rahim Moosavinia ${ }^{2}$ \\ ${ }^{I}$ Department of English Language and Literature, Boroujerd Branch, Islamic Azad University, Boroujerd, Iran \\ ${ }^{2}$ Shahid Chamran University of Ahvaz, Ahvaz, Iran \\ Shvzaheri@gmail.com
}

\begin{abstract}
This paper attempts to analyze the mentioned novel based on postcolonial studies in Arundhati Roy's The God of Small Things. The concepts that can be mentioned in this novel are history, diaspora, hybridity, the role of women in Indian society, globalization, resistance and orientalism. These concepts are used from postcolonial theorists, Edward W. Said and Homi K. Bhabha.Prominent issue is the role women in Indian society, because there are several female characters, such as Ammu, Rahel, and so on in TGST. Economic growth causes change in Ayemenem. It becomes a globalized community. Postcolonial resistance is an important issue in the novel. When Roy uses English language which it is a colonial language, she does a kind of resistance against colonization itself. Roy refers to the children's life as a means of resistance.
\end{abstract}

Keywords: Colonial discourse; postcolonialism; other; resistance; diaspora; feminism.

\section{Introduction}

The present researcher believes that it may be seen as a kind of Orientalism in TGST. Loomba, in her book Colonialism/Postcolonialism (1998), believes that anti-colonial or nationalist movements have tried to show the image of the Nation-as-Mother to make their own ancestors "and also to control the activity of women within the imagined community. [...] these movements encourage women to create 'sons who may live and die for the nation" (180). The nation is shaped as a home, and its leaders are like paternal roles and fellowcitizens are brothers and sisters. For example, "the King was a Father to his people" (ibid 81). The family and the State completed each other.In colonialism, the family becomes the symbol of anti-colonial movement because it indicates inner space (182). When appropriated families of colonized subjects in colonial situation and intrusions were imagined, "the family will be symbol of resistance" (ibid).

Here, the ideal woman is in opposition to the memsahib. The ideal woman is drawn by brahminical notions of female self-sacrifice and devotion. When an ideal gentlewoman is constructed, this woman is separated from their lower- class sisters, who are servants or sources of folk or popular music and tales, dramas and wit. In this condition, many forms of women's popular culture are marginalized. These forms expressed difficulty of women "in male-dominated society or sexual desire using powerful humour, sharp" (ibid). Women are half the population of any nation. Even we know little or nothing about the "widows themselves and of the fact of their pain" (ibid 185). The discussions around these "widows" have a striking place within postcolonial theory because they "are the agency of the colonized" (ibid). The women's voices become absent in the immolation discussion. This absence shows the "intermixed violence of colonialism and of patriarchy" (ibid). Women are "real targets of colonialist ad nationalist discourses" (ibid).

According to Loomba, in her book Colonialism/Postcolonialism (1998), there are "some writings of women for eminent scholars" (186). These writings worked a long side, within or in opposition to the nationalist and anti-colonial notions. The more feminist study

DOI : https://doi.org/10.33258/birci.v2i4.561 
retrieves the lives of women under colonial rule, and it shows "women as individuals as a potential collectivity" (Loomba 186). They were the target of earlier patriarchal rewritings of tradition. Anti-colonial struggles are different in their attitudes to "female agency and women's rights" (ibid). Ghandhi has non-co-operation movement. It is called "proto feminist" (ibid 187). Gandhi ignored women's fighting, and followed "the conceptions of the family and society" (ibid). In India, women's fighting confronted strong political interaction. In the nineteenth century, "women" were not in "any public anti-colonial protests" (ibid). The terms shaped at that time caused to make "the nationalist movement from 1920s onwards" (ibid). Women's roles were expansion of "their household roles-caring", "subservient", "nonmilitant" (ibid).

There were some attempts "to restrict their agency" (ibid). Moreover, women had various responses against these attempts. Many women were active in colonial struggles. These women were not feminist; they did not see tension between their own struggles and those of their community at large. They worked outside purely household spaces, some women were leadership. These women explained new conceptual spaces for women. They went "into public spaces in the name of motherhood and family" (ibid). In addition, Loomba mentiones that:

Women continue their struggles for equality after formal independence and describe the nature of postcoloniality. Anti-nationalisms legitimized women's public activity. Postcolonial countries more easily admit women's participation in politics than metropolitan ones because of this nationalist legacy. In recent years, there has been an effort to exploit women's political activity and even religious fundamentalism. The Hindu, Islamic or Christian right-wing movements are taken place by active women in the different parts of the world. Women used trickily the question of religion. "It has surfaced as a major factor in women's relationship to the nation and to postcolonial politics". Many postcolonial systems repressed women's rights, and used religion to reinforce their subordination. The Islamicisation of civil society constructed national identity in Pakistan, Bangladesh, Afghanistan, and Saudi Arabia. Religion has a key role 'in mutations of postcolonial identities and gender roles. Islam is understood as more prone fundamentalist appropriation than any other religion'. In India, women like SadhviRithambara and Uma Bharati are key players for Hindu nationalism by entreating fears of Muslim fierceness'. 'Women are objects as well as subjects of fundamentalist discourses. The relationship between women, nation and community is variable, both in the colonial period and afterwards. Colonial and anti-colonial histories complicate feminism. Women tried to struggle for self-determination, democracy, anti-imperialism and re-shaped their under-standing of themselves. Amerita Base suggests that women had participated in nationalist struggles in contemporary period. (189)

A national feminist conference was been disposed in 1987, 79 percent of the members were active in black, labour, working- class, church, and other political movements. Women are known with more anti-imperialist or working-class than with the concerns of white First world feminism. The women's movements have been divided according to class, colour, religion, location, sexuality and politics. Black women in the USA may have the politics of white feminism, but the independent feminists regard the issues of sexuality and fierceness in India. "Nationalist or class-based movements" have subordinated questions of "women's sexuality or autonomy" (Loomba 190).

In India, women's movements try to pay to the questions of sexual and household fierceness and also of equal pay for equal work. Totally, postcolonial 
women's movements have fought 'against state repression rape, racism, patriarchy, or better working conditions and for choice of sexual direction'. Postcolonial women's movements have tried to defy the assumption that they are inspired by its Western counterparts. These movements follow their local and native roots. They re-wrote local histories, pro-co women's rights, and used religion to reinforce their subordination. The Islamicisation of civil society constructed national identity in Pakistan, Bangladesh, Afghanistan, and Saudi Arabia. Religion has a key role 'in mutations of postcolonial identities and gender roles. Islam is understood as more prone fundamentalist appropriation than any other religion'. In India, women like SadhviRithambara and Uma Bharati are key players for Hindu nationalism by entreating fears of Muslim fierceness'. 'Women are objects as well as subjects of fundamentalist discourses. The relationship between women, nation and community is variable, both in the colonial period and afterwards. Colonial and anti-colonial histories complicate feminism. Women tried to struggle for self-determination, democracy, anti-imperialism and re-shaped their under-standing of themselves. Amerita Base suggests that women had participated in nationalist struggles in contemporary period. (189)

A national feminist conference was been disposed in 1987, 79 percent of the members were active in black, labour, working- class, church, and other political movements. Women are known with more anti-imperialist or working-class than with the concerns of white First world feminism. The women's movements have been divided according to class, colour, religion, location, sexuality and politics. Black women in the USA may have the politics of white feminism, but the independent feminists regard the issues of sexuality and fierceness in India. "Nationalist or class-based movements" have subordinated questions of "women's sexuality or autonomy" (Loomba 190).

In India, women's movements try to pay to the questions of sexual and household fierceness and also of equal pay for equal work. Totally, postcolonial women's movements have fought 'against state repression rape, racism, patriarchy, or better working conditions and for choice of sexual direction'. Postcolonial women's movements have tried to defy the assumption that they are inspired by its Western counterparts. These movements follow their local and native roots. They re-wrote local histories, pro-colonial symbols and mythologies, and express their voice. Today, these movements have to debate "the dynamics of globalization", and "the postcolonial nation-state" (ibid 191).

In addiation, Loomba mentions that earlier women's labour directly or indirectly enforced the colonial machine. "Globalization" often reproduces "the general effects of colonialism" (ibid). These women's labours are now experimented by medical experiments, and there are "the receivers of drugs and contraceptives banned in the West" (ibid 192). Fundamentalists believe that Western or imperialist forces are "responsible for all manner of evil, such as women's repressions" (ibid 192). But globalizations make an "international women's development network" (ibid). The governmental or feminist organizations try "to improve women's health", or "working conditions", also "moving enlightenment from the West to the rest of the world" (Loomba 192). "Global imbalances profoundly structure feminist agendas in the postcolonial world" (ibid). In postcolonial communities, women have attended fully postcolonial politics, "from the established forms of political action to the new social movement such as, environmental programmers" (ibid). 


\section{Methodology}

The present researcher tries to analyze the novel based on some postcolonial concepts. Hybridity is based on White who believes that history is the title of scientific discipline in the nineteenth century. In postcolonial regions, there is migration and transition of the different nations always. In the result of this transition of the peoples, the new identities had been made .This condition createstranscultural identity. Hybridity became significant concept in postcolonial studies. The present researcher tries to work on diaspora and hybridity from Bhabha's view. The writer and the character of Ammu are women. And they belong to diasporic community, the researcher wants to work on the role of women in Indian society. Other concepts are resistance and orientalism. Said worked on the two last concepts. The process of the world shrinking and becoming a single place refers to globalization. This happens in complex society. India tries to inject foreign investment for globalization.

\section{Discussion}

\subsection{The Role of Women in Indian Society in the God of Small Things}

Roy dares to cross the boundaries of caste to face the most hideous form of ostracisation and stands on the fringes of Indian society. Indian society does not provide any satisfactory choice to women who stand apart from the usual pattern of accommodation to wifehood and integration into the in-laws. Thus, transgression is regarded by patriarchy not enough powerful to disrupt the natural established order, though to some extent, particular individual actions affect social reactions, and exclusion/death remain specifically the ultimate punishments. Yet, the philosophy of Hindu women, i.e. passive resistance is disturbing. On the one hand, this supposes that women have no choice, although Western interpretations challenge this deeply socio-religious rooted myth. Western women are to free Indian women from such typecasting and promote more direct actions. Certainly, moral superiority is a myth that could keep women stranger to themselves, judges of other women if not fearful or contemptuous towards their male counterparts. Indeed, Indian women could experience a vast array of human emotions and actions beyond defined Indian traditional women roles.

A woman protagonist leads a life in complete conflict with traditional values. The novel implies the traditional ways of life are changing and women are starting to think in a different way. It is deconstructing stereotyped representations of some aspects of Indian family life and culture which shape it, i.e. a rigid interpretation of the Sacred Book (The Vedas), established sexist prejudice, a tight family budget in a society that still privileges dowry and the belief that a Hindu woman belongs to her husband's family. Through the process of construction and deconstruction of the woman protagonist, the novel demonstrates the power of literature to create awareness and sensitivity of the struggles that the main woman character faces are the result of the changing times, notably the inner workings of her minds, her personal perplexities and social confrontations as individual growing into themselves. We can see this matter in this part of the novel in which Amm's brother, Chacko, decided about Ammu's relationship with Velutha.

In TGST, the primary purpose is the isolation of the individual soul, particularly of woman, and the secondary purpose is the political considerations. The novel seeks to define the many voices of the previously marginalized otherand establish a claim to woman cultural 
identity. Woman's selfhood has been subordinated, diminished when it has not been outrightly denied. An important step in recognizing the interconnections between the local (India) with the global (diasporic) is exploding cultural stereotypes that determine a self in terms of otherby locating India on the opposite side of the tradition vs. modernity dichotomy.

In TGST, the concept of hybridity is revealed in its simple sense, i.e. a blending of two cultures and in the interest of individual progressive thinking and social justice. In fact, conservative Hindu spreading that set up monolithic cultures has disturbing implications for Indian women who have a stake in challenging patriarchal/traditional Indian behavior and thinking.

The woman has an in-between space in the postcolonial debate which "allows for much diversity and flexibility in identity" (Bhabha 1994: 211). Criticism of colonialism on an ideological basis and the stress on the colonizer / colonized dichotomy exclude hybrid groups. But, hybrid groups that developed as an impact of colonialism represent a fundamental sign of domination and exploitation. These women have to create their own identity between both of two cultures. Racial hybridity is extremely important since they do not define themselves as either Anglo or Indian solely. They resist complete identification with the Indian and the British and claim their own space and subjectivity. They have a generous space of culturality within which they can operate as individuals. The in-between spaces lead to "new signs of identity and innovative sights of collaboration and contestation in the act of defining the idea of society itself" (Bhabha 1994: 2).

TGST challenges static notions of identity, specifically the construction of third world or post-colonial women. Indian women are located in terms of underdeveloped, oppressive, highly illiterate and religious fanaticist. Postcolonial Indian writer, as feminist argues that she needs to engage critically with the historically specific and dynamic location of women in India so as to a participate in cultural reproductions that reduce women's lives to a particular fixed patriarchal pattern and to avoid over creating binary appositions between modern, educated, free, Western women, and oppressed, poor, traditionally bound third world women. In an attempt to reclaim and write against the representation of third world women as the exoticised other, Roy serves political aims by writing against patriarchy. Yet she writes in the context of a society/community whose members do not have the luxury skills to read and write but are nevertheless the ones who represent and speak for these women.

Roy's novel based in India which the cross-cultural undercurrents are spanning continents, gives a new vision of Indian women, pleasing to Western mind and feelings and yet, reflecting partly Indian woman to come to terms with her self, a process which would certainly have not been affected within the particular socio-cultural location. In the novel, Indian women who resisted Hindu traditions are accused of transgressing and violating the oppressive patriarchal patterns within Indian family structure and therefore are condemned to ostracisation up to death.

As to the postcolonial diaspora, it is not solely immigration into Great Britain or elsewhere from other countries, but it is indeed a constant reminder that pre-colonized subjects are in the colonizers' land because they were in their own homeland. The specific phenomenon of immigration transgresses Western British sense of fixed boundaries and challenges the cultural identity of the White Englishman/woman as being homogeneous. It is perceived probably as threat to British national cohesion. The choice of Indian diasporic women is not only colonization in reverse and the voice of the other, but also the voice of hybridity. This diasporic novel struggles with patriarchy. Diasporic women need not solely 
define themselves in terms of their difference from mainstream of their countries of birth, but there is also this urge to differentiate from the country that lies behind them. This crucial need to escape, takes place in the context of differentiating and making a space for the Indian woman writer. It is especially the presence of various contradictory and sophisticated ideologies within the diasporic communities that renders Indian women's works so fruitful for queries of women identity and existence at a micro level from steady examinations of family li Roy's novel based in India which the cross-cultural undercurrents are spanning continents, gives a new vision of Indian women, pleasing to Western mind and feelings and yet, reflecting partly Indian woman to come to terms with her self, a process which would certainly have not been affected within the particular socio-cultural location. In the novel, Indian women who resisted Hindu traditions are accused of transgressing and violating the oppressive patriarchal patterns within Indian family structure and therefore are condemned to ostracisation up to death.

As to the postcolonial diaspora, it is not solely immigration into Great Britain or elsewhere from other countries, but it is indeed a constant reminder that pre-colonized subjects are in the colonizers' land because they were in their own homeland. The specific phenomenon of immigration transgresses Western British sense of fixed boundaries and challenges the cultural identity of the White Englishman/woman as being homogeneous. It is perceived probably as threat to British national cohesion. The choice of Indian diasporic women is not only colonization in reverse and the voice of the other, but also the voice of hybridity. This diasporic novel struggles with patriarchy. Diasporic women need not solely define themselves in terms of their difference from mainstream of their countries of birth, but there is also this urge to differentiate from the country that lies behind them. This crucial need to escape, takes place in the context of differentiating and making a space for the Indian woman writer. It is especially the presence of various contradictory and sophisticated ideologies within the diasporic communities that renders Indian women's works so fruitful for queries of women identity and existence at a micro level from steady examinations of family life and negotiations to the ideological religious imperatives that features Roy's novel.

The novel represents the life of an Indian woman rethinking and reconstructing her identity. Each woman feels marginalized in her own socio-cultural location and ultimately tries to locate herself in the central position. The legacy of British colonialism has meant that Indian women now live outside their native land with different perspectives on postcolonial issues, raising specific voices which are powerfully articulated in their own defense.

Indeed, postcolonial Indian women novel emerged as a process that gathered space as political independence was acquired and cultural decolonization intensifies. Given that writing in English by women has developed greatly for obvious historical reasons, Indian women writing could be described as writing backto the dominant English as a quest for the establishment of woman cultural authority English serves as an ideological purpose and propagates Western culture among the colonized. But, Indian women writer has illustrated the power by which language with its signification of authority has been wrested from the dominant cultural. Roy is writing from positions between or across cultures and revalorizing marginalized cultural women identities. The construction/deconstruction of hybrid diasporic women identity related to gender and caste are among the social concerns shaping the work of the writer.

This powerful written testimonial mirrors the power of writing and literacy to free women's lives from the chains of a restrictive real-life milieu. The writer is speaking of her 
own experience in her own voice. She finds it hard to set up a balance between her femininity and autonomy, her Hindu traditions and Western modernity. She is both as woman and as racially different, into the receiving/ host society, her writing reflects certainly her disagreement with the officially accepted construction of correct behavior, aware of the problems of traditionally structured disadvantages.

Roy criticizes traditional networks which remain active in India to repress women's ideas, impulses and feelings in conscious and unconscious ways. Her writing in English is undoubtedly an inward thought as well as a personal release from Indian socio-cultural and political boundaries though shared by Indian feminist writers.

A woman writer highly criticizes certain kinds of women within a text. For example, the most evil figure in TGST is an older woman, the spinster aunt. She is absolutely malevolent, almost monstrous in her malevolence, and it is she who triggers most of the disasters that occur. Sometimes a woman writer tries to supposed to say good things about women. Roy is very good at showing the ways in which women of all classes and all generations are positioned by socio-cultural systems. Even this aunt, Baby Kochamma, is very much embittered as a consequence of her own history, and we are shown precisely how she has grown to be the way she is; not that it excuses her horrible actions, but Roy gives you a very complex picture of the dynamics that interplay between cultural constraints and individual choice.

\subsection{Postcolonial Resistance in The God of Small Things}

Colonization refers to the domination of a group people over people's land and goods. Colonialism refers to the domination of various European powers into other land in the world and it refers to a feature of human history. Colonialism essentially refers to a period of history from the late fifteenth and the twentieth century. This notion rests during the history of human life. The colonial rulers affected the lives of the colonized population. These rulers believed that they have superiority and ordained mandate to rule over colonized population. The colonies were full of labour and human resources. British Empire colonized lands through the world such as India, America, Canada, and Australia.The British colonization affected Indian society, culture and literature. Literature creates new genres, ideas and identities. Such as John Donne some writers or poets use colonialist concerns in their writings. Literary texts can oppose dominant ideologies. Moreover, many of English novels were written about India during the British colonization. In the nineteenth century, British literature represented that imperialism was an important part of the cultural representation of England to the English. Another aspect of the relation between literature and colonialism refers to dominant critical views, which sanctified within educational systems. Britain changed literary studies to a discipline of study in British universities for colonial administrators instructed in Western literature. Colonialism and literature are related to each other.

The British colonization affected Indian society, culture and literature. Literature creates new genres, ideas and identities. Such as John Donne some writers or poets use colonialist concerns in their writings. Literary texts can oppose dominant ideologies. Moreover, many of English novels were written about India during the British colonization. In the nineteenth century, British literature represented that imperialism was an important part of the cultural representation of England to the English. Another aspect of the relation between literature and colonialism refers to dominant critical views, which sanctified within 
educational systems. Britain changed literary studies to a discipline of study in British universities for colonial administrators instructed in Western literature. Colonialism and literature are related to each other.

Postcolonialism is a subject of debate in contemporary literary and critical studies. This is a state after the formal end of colonialism. This is originated from the Western. It depends on Western philosophy labeled as the Euro-centric. It is a complex phenomenon that is embodied with excessive jargon and branded as he latest catchall term to dazzle the academic mind. The postcolonial Indian English fiction reflects the spirit of different regional literature as a whole. The concept of nation became a curious debate in the postcolonial study. The postcolonial Indian English fiction witnesses at least three generations of Indian novelists in English. Arundhati Roy belongs to the third generation. She established the frame in international arena. Indian English fiction succeeded to win almost every well-known literary prize in the world. In colonialism, the family becomes the symbol of anti-colonial movement because it indicates inner space. The family will be symbol of resistance. The repressed peoples make anti-colonial nationalism to represent a selfhood during colonial rule. The image of nation as a mother indicates both female power and female helplessness. This mother defends her son against colonial pillages, but it is also herself devastated by colonialism and she needs her son's protection. In Indian culture, the ideal woman is drawn by "brahminical notions of female self-sacrifice and devotion" (Loomba 183). In Indian society, women's fighting confronted strong political interaction. Gandhi ignored women's fighting, and followed the conceptions of the family and society. Many women were active in colonial struggles. They were not feminist; they did not see tension between their own struggles and those of their community at large. They went into public spaces in the name of motherhood and family. Women continue their struggle for equality after formal independence and describe the nature of postcoloniality. Postcolonial countries more easily admit women's participation in politics than metropolitan ones because of this nationalist legacy. The Hindu, Islamic or Christian right-wing movements are taken place by active women in different parts of the world. Women used trickily the question of religion. Many postcolonial systems repressed women's rights, and used religion to reinforce their subordination. In India, women like SadhviRithmabara and Uma Bharati are key players for Hindu nationalism by entreating fears of Muslim fierceness'.

The relationship between women, nation and community is variable, both in the colonial period and afterwards. Women try to struggle for sel-determination, democracy, antiimperialism and re-shaped their understanding of themselves. Totally, postcolonial women's have fought "against state repression rape, racism, patriarchy, or better working conditions and for choice of sexual direction" (Loomba191). Postcolonial women's movements follow their local and native roots. They re-wrote local histories, pro-colonial symbols and mythologies, and expressed their voice. Today, these movements have to debate the dynamics of globalization, and the postcolonial nation-state. "Globalization often reproduces the general effects of colonialism" (ibid). Globalization makes an international women's development network. "The governmental or feminist organizations" try to improve "women's health", or "working conditions", also moving "enlightenment from the West to the rest of the world" (Loomba 192). In postcolonial communities, women have attended in the full range of postcolonial politics, "from the more established forms of political action to the social movement" such as, environmental programmers (ibid). Women's labours are 
experimented by medical experiments, and there are the receivers of drugs and contraceptives banned in the West.

\section{Conclusion}

In conclusion,prominent issue is the role women in Indian society, because there are several female characters, such as Ammu, Rahel, and so on in TGST. Economic growth causes change in Ayemenem. It becomes a globalized community. Postcolonial resistance is an important issue in the novel. When Roy uses English language which it is a colonial language, she does a kind of resistance against colonization itself. Roy refers to the children's life as a means of resistance. The present researcher believes that it may be seen as a kind of Orientalism in TGST. The results are given in a final item, the conclusion.History is a significant feature in the postcolonial works. According to Ashcroft et al, in Postcolonial Studies Reader (2006), White believes that history seeks "the title of scientific discipline in the nineteenth century mould" (17). There are various layers of history in TGST such as, the history of Syrian-Christian in South India, the history of the caste system in Hinduism, Velutha as the Hindu God, Krishna, kathakali dance in Kerala, Communism Party in Kerala, Naxalites in Kerala. Kerala is a complex community. The people with different beliefs live in Kerala. Communism was so much more successful in Kerala. Because according to Communism, the people must be equal to each other. So the lower class follows it in Kerala.

Diaspora is an important issue which was significant in TGST. Diaspora has taken place in various layers of the Indian history. Diaspora has mostly taken place during migration and transition. Hybridity is unavoidable in diasporic communities such as, Kerala. Kerala was a complex and diasporic society. Hybridity refers to an in-between space. Bhabha believes that the in-between space "allows for much diversity and flexibility in identity" (Bhabha 1994:211). There were biological, cultural and linguistic hybridity in TGST. The researcher believes that hybridity is dangerous, because the character of Ammu declined by her illegal relationship with Velutha and the twins declined by their incest (adultery between close relatives) at the end of the novel. These characters had cultural hybridity and it caused their declines.

The novel challenged static notions of identity, specifically the construction of postcolonial women too. Roy as a hybrid diasporic woman tried to relate to gender and caste among other social concerns. She tried to express her own experience in her own voice. She used the Western language against colonialism itself. It is a kind of resistance.India injected outside investment as part of its economic liberation in early 1990s. Kerala was affected by this plan. This plan made economic growth. And Kerala becomes globalized. Roy believed that globalization increased social inequalities in India. This globalization made sharply divide between rural and urban India. India's future depends on its plurality and its political alternatives. What is received in this novel is diaspora made in the different historical layers. And hybridity happens in the result of diaspora. And hybridity is dangerous, because two characters decline in the novel. And the future of India is in local, not globalization. Indian government should have political alternatives. 


\section{References}

Anderson, Benedict. (1983). Imagined Communities. London and New York: Verso.

Ashcroft, Bill et al. (2002) . The Empire Writes Back.London and New York:

-------. (2007). Postcolonial Studies (The Key Concepts). New York: .Routledge.

Basirizadeh, Fatemeh Sadat. (2019). A Comparative Study of the Psychoanalytical Portrayal of the Women Characters by Virginia Woolf and Zoya Pirzad. Britain International of Humanities and Social Sciences, 1-8.

Gaeini \& Basirizadeh. (2019). The Role of social Identity in James Joyce s Dubliners within the Light of Cultural Materialism. Budapest International Research and Critics Institute (BIRCI-Journal), 89-99.

Wisker, Gina. (2007). Key Concepts in Postcolonial Literature. London: Palgrave.

Said, Edward. (2003). Orientalism. London: Penguin Books.

Tickell, Alex. (2007). Arundhati Roy's The God of Small Things. New York: Routledge

W. Conolly. (2005). Encyclopedia of Postcolonial Literatures .Benson, Eugene and L in English. New York: Routledge. 